\title{
ANALISIS USAHA PEMANFAATKAN TEPUNG LIMBAH IKAN GABUS PASIR (Butis amboinensis) PADA ITIK PEKING UMUR 1 HARI SAMPAI 8 MINGGU
}

\author{
Utilization of Business Analysis Meal Fish Waste Cork Sand (Butis \\ amboinensis) to Peking Duck Age 1-8 Sunday
}

\author{
Heri Nirwanto ${ }^{1}$, Armyn Hakim Daulay ${ }^{2}$, Hasnudi ${ }^{2}$ dan T. Vidiana Sari ${ }^{2}$ \\ 1. Mahasiswa Program Studi Peternakan Fakultas Pertanian Universitas SumateraUtara \\ 2. Staf Pengajar Program Studi Peternakan Fakultas Pertanian Universitas Sumatera Utara
}

\begin{abstract}
The purpose of this study is to analyze the business utilization of gabus pasir waste fish meal on the cost of production, profit / loss, income over feed cost (IOFC) and the revenue cost ratio $(R / C$ ratio). Research conducted at the Laboratory of Animal Biology, Agricultural Faculty, University of Sumatera Utara, from August to October 2014. The method used is the method of survey and economic analysis. The study consisted of 3 treatments and 6 replications. The treatment consisted of ratio commercial fish meal with gabus pasir waste fish meal PO (10\%:0\%), P1 (5\%:5\%), P2 (0\%:10\%) in diet. The results showed that the treatment the average total cost on treatment P0; P1; P2 were (Rp/head/period): 45.905,52; 45.092,33 and 44.857,98, Revenue (Rp/head/period): 46.188,33; 46.779,83 and 47.868,33, profit / loss (Rp/head/period): 282,80; 1.687,50 and 3.010,34, income over feed cost (IOFC) (Rp/head/period): 17.673,12; 19.077,81 and 20.400,88 and R / C ratio, respectively: 1.01; 1.04 and 1.07, respectively. Utilization of gabus pasir waste fish meal with a level of $10 \%$ can increase the total income, $R$ / C Ratio, profit and loss analysis and IOFC (Income Over Feed Cost). The conclusion of this research gabus pasir waste fish meal level of $10 \%$ can increase revenues and able substituen commercial fish meal in diet for peking duck.
\end{abstract}

Keywords: Business Analysis, gabus pasir waste fish meal, Peking duck

\begin{abstract}
ABSTRAK
Tujuan penelitian ini adalah untuk menganalisis usaha pemanfaatan tepung limbah ikan gabus pasir terhadap biaya produksi, hasil produksi, laba/rugi, income over feed cost (IOFC) dan revenue cost ratio (R/C ratio). Penelitian dilaksanakan di Laboratorium Biologi Ternak Fakultas Pertanian Universitas Sumatera Utara, yang berlangsung pada bulan Agustus sampai Oktober 2014. Metode penelitian yang digunakan adalah metode survey dan analisis ekonomi. Penelitian tediri dari 3 perlakuan dan 6 ulangan. Perlakuan menggunakan perbandingan tepung ikan komersial dengan tepung limbah ikan gabus pasir antara P0 (10\%:0\%), P1 (5\%:5\%), P2 (0\%:10\%). Hasil penelitian menunjukkan bahwa pada perlakuan P0, P1 dan P2 memberikan hasil yang berbeda terhadap rataan total biaya produksi (Rp/ekor/periode): $45.905,52 ; 45.092,33$ dan $44.857,98$, total hasil produksi (Rp/ekor/periode): 46.188,33; 46.779,83 dan 47.868,33, laba / rugi (Rp/ekor/periode): 282,80; 1.687,50 dan 3.010,34, income over feed cost (IOFC) (Rp/ekor/periode): 17.673,12; 19.077,81 dan $20.400,88$ dan R / C ratio : 1.01; 1.04 and 1.07. Kesimpulan dari penelitian ini menunjukan bahwa Penggunaan tepung limbah ikan gabus pasir dengan level 10\% dapat meningkatkan total hasil produksi, R/C Ratio, analisis laba rugi dan IOFC (Income Over Feed Cost). Dan dapat menurunkan harga pakan, biaya konsumsi dan total biaya produksi pada pemeliharaan itik peking. Penggunaan tepung limbah ikan gabus pasir dengan level 10\% dapat meningkatkan pendapatan dan menggantikan tepung ikan komersil dalam ransum ternak itik peking.

Kata kunci : Analisa Usaha, Tepung Limbah Ikan Gabus Pasir, Itik Peking.
\end{abstract}




\section{PENDAHULUAN}

Analisis usaha merupakan kegiatan penting dalam usaha peternakan dan merupakan pekerjaan rutin perusaan peternakan yang dilakaukkan untuk mengetahui kelayakan suatu usaha peternakan. Keadaan perusaan seperti besarnya biaya yang dikeluarkan, pendapatan bersi, serta ukuran efisiensi dan efektifitasnya usaha yang digambarkan melalui analisis usaha ekonomi. Selain itu sebagai landasan dalam menentukan kebijakan usaha kedepannya.

Di negara agraris Indonesia, ternak itik merupakan salah satu ternak unggas yang cukup dikenal masyarakat. Itik memberikan dua hal kepada manusia untuk memenuhi kebutuhan pangannya, yaitu daging dan telur (Samosir, 1981)

Peternakan itik di Indonesia sampai saat ini masih menghadapi kendala baik secara teknis maupun ekonomi. Salah satu diantaranya adalah penyedian ransum karena faktor ransum juga ikut menentukan besar kecilnya keuntungan dari suatu usaha peternakan. Untuk itu perlu dicari alternatif bahan pakan yang tersedia secara terus menerus.

Harga ransum ternak unggas yang semakin mahal pada saat ini, tidak sebanding dengan penghasilan dari produksi yang didapat oleh peternak. Hal ini dikarenakan selama ini indonesia mengimpor bahan baku pakan yang potensial, untuk itu perlu dicari bahan pakan yang potensial alternatif yang diharapkan dapat menekan kenaikan harga ransum unggas dan tidak melupakan aspek biologisnya. Penggunaan bahan pakan alternatif yang ekonomis akan memperoleh efesiensi ransum dan produksi (Murtidjo, 1987).

Limbah perikanan salah satu alternatif untuk memberi solusi dalam memenuhi kebutuhan ransum. Limbah merupakan buangan yang dihasilkan dari suatu proses produksi baik industri maupun domestik (rumah tangga). Limbah yang tidak dapat dikendalikan dapat mencemari lingkungan yang mengakibatkan sumber ketidaknyamanan bagi masyarakat lingkungan sekitar.

Salah satu limbah yang diketahui banyak terdapat di daerah Belawan, yang merupakan suatu tempat yang berpotensi menghasilkan limbah dari jenis ikan. Daerah Belawan merupakan salah satu pusat perdagangan ikan yang ada di Sumatera Utara yang cukup besar, ikan-ikan tersebut yang akan di distribusikan ke pasar-pasar yang ada di kota Medan. Jarak yang ditempuh dari Medan ke Belawan berkisar $\pm 25 \mathrm{~km}$ dan dapat ditempuh dengan menggunakan angkot maupun sepeda motor.

Limbah ikan yang ada di Belawan salah satunya yaitu limbah ikan gabus pasir, yang merupakan jenis ikan yang banyak hidup di pesisir pantai dan mudah di dapat. Tempat yang banyak memproduksi ikan ini yaitu KUD (Koperasi Unit Desa) yang merupakan salah satu. 
Tempat Pelelangan Ikan (TPI) yang berada di Jalan Gabion Kecamatan Medan Belawan. Produksi dari ikan ini dapat mencapai 1 ton/hari, yang merupakan produksi cukup besar di daerah belawan. Ikan gabus pasir hanya dimanfaatkan dagingnya saja, sedangkan isi perut dan kepala hanya dibiarkan begitu saja dan tidak dimanfaatkan. Daging dari ikan ini banyak di produksi sebagai bahan campuran pembuatan bakso yang banyak di perjual belikan di pasar, namun ada juga yang mengekspor daging dari ikan gabus pasir tersebut.

Pengolahan dari limbah ikan gabus pasir dapat berupa tepung, yang nantinya dapat dimanfaatkan sebagai bahan campuran ransum ternak. Tepung limbah ikan gabus merupakan salah satu produk pengolahan hasil ikan. Sifat ikan yang sangat mudah rusak ini memerlukan penanganan dan pengolahan yang pada dasarnya bertujuan untuk mencegah kerusakan atau pembusukan sehingga dapat memperpanjang daya tahan simpan ikan. Sampai saat ini penggunaan tepung ikan gabus pasir belum dilakukan secara maksimal.

Pembuatan tepung ikan berbahan dasar limbah ikan gabus dapat menjadi suatu bentuk alternatif bahan pakan. Selain memiliki daya simpan yang cukup lama dibandingkan dengan ikan segar, bentuk yang berupa tepung diharapkan menjadikan tepung ikan lebih fleksibel dalam pemanfaatannya.

\section{BAHAN DAN METODE PENELITIAN}

\section{Lokasi dan Waktu Penelitian}

Penelitian ini dilaksanakan di Laboratorium Biologi Ternak Program Studi Peternakan Fakultas Pertanian Universitas Sumatera Utara Penelitian ini berlangsung selama 8 minggu.

\section{Bahan dan Alat}

Bahan yang digunakan yaitu itik peking umur 1 hari (Day Old Duck (DOD)) sebanyak 90 ekor, bahan penyusun ransum terdiri dari jagung, dedak padi, bungkil kelapa, bungkil kedelai, tepung ikan, minyak nabati, bungkil inti sawit, tepung limbah ikan gabus pasir, top mix, air minum memenuhi kebutuhan air didalam tubuh yang diberikan secara ad libitum, air gula untuk mengurangi stress dari kelelahan transportasi, rodalon sebagai desinfektan kandang dan peralatan tempat pakan dan minum, formalin $40 \%$ dan $\mathrm{KMnO}_{4}$ (Kalium permanganate) untuk fumigasi kandang, vitamin dan suplemen tambahan seperti Vitachick, Vaksin ND strain Lasota.

Adapun alat yang digunakan yaitu kandang baterai berukuran $100 \mathrm{~cm} \times 100 \mathrm{~cm} \times$ $100 \mathrm{~cm}$, sebanyak 18 unit dan setiap unit di isi 5 ekor DOD, peralatan kandang terdiri dari 18 unit tempat pakan dan 18 unit tempat minum, timbangan salter digital kapasitas $3000 \mathrm{gr}$ untuk menimbang bobot badan itik dan menimbang ransum, alat penerang dan pemanas 
berupa lampu pijar 40 watt sebanyak 18 buah, thermometer sebagai pengukur suhu kandang. Alat pencatat data seperti buku data, alat tulis dan kalkulator, alat pembersih kandang berupa sapu ember, sekop dan hand sprayer, alat lain berupa plastik ember dan pisau.

\section{Metode Penelitian}

Penelitian ini merupakan rangkaian penelitian sebelumnya yang meneliti tentang performan dengan menggunakan metode rancangan acak lengkap (RAL) dengan 3 perlakuan 6 ulangan. Adapun perlakuan tersebut yaitu:

$\mathrm{P} 0=$ Penggunaan ransum kontrol dengan tepung limbah ikan gabus pasir sebanyak $0 \%$ dan tepung ikan komersil 10\%

$\mathrm{P} 1=$ Penggunaan ransum dengan tepung limbah ikan gabus pasir sebanyak $5 \%$ dan tepung ikan komersil 5\%

$\mathrm{P} 2=$ Penggunaan ransum dengan tepung limbah ikan gabus pasir sebanyak $10 \%$ dan tepung ikan komersil 0\%

Setelah penelitian performans dianalisis, dilanjutkan penelitian dengan analisis usaha untuk mengetahui perlakuan mana yang dapat meningkatkan nilai ekonomis. Untuk itu digunakan metode survey untuk mengetahui harga bibit, sewa kandang, harga obat-obatan, harga peralatan kandang dan harga tenaga kerja.

\section{Parameter Penelitian}

\section{Total Biaya Produksi}

Total biaya produksi atau total pengeluaran yaitu biaya-biaya yang dikeluarkan untuk menghasilkan suatu produk yang diperoleh dengan cara menghitung: biaya pakan, biaya pembelian bibit, biaya obat-obatan, biaya sewa kandang dan peralatan serta biaya tenaga kerja. 
Tabel 1. Harga ransum yang digunakan pada saat penelitian periode starter dan finisher

\begin{tabular}{lccc}
\hline Bahan pakan & $\begin{array}{c}\text { Perlakuan P0 } \\
(\mathrm{Rp} / \mathrm{Kg})\end{array}$ & $\begin{array}{c}\text { Perlakuan P1 } \\
(\mathrm{Rp} / \mathrm{Kg})\end{array}$ & $\begin{array}{c}\text { Perlakuan P2 } \\
(\mathrm{Rp} / \mathrm{Kg})\end{array}$ \\
\hline A. Periode Starter & 0 & 343 & 676 \\
TLIGP & 750 & 375 & 0 \\
Tepung Ikan & 298 & 298 & 298 \\
Dedak Padi & 1.383 & 1.383 & 1.383 \\
Tepung Jagung & 1.800 & 1.800 & 1.800 \\
Bungkil Kedelai & 315 & 315 & 315 \\
Bungkil Kelapa & 207 & 207 & 207 \\
BIS & 100 & 100 & 100 \\
Mineral & 360 & 360 & 360 \\
Minyak Nabati & $\mathbf{5 . 2 1 2}$ & $\mathbf{5 . 1 8 0}$ & $\mathbf{5 . 1 4 1}$ \\
\hline Harga ransum (Rp/Kg) & & & 676 \\
\hline B. Periode Finisher & 0 & 343 & 0 \\
TLIGP & 750 & 375 & 210 \\
Tepung Ikan & 210 & 210 & 1.600 \\
Dedak Padi & 1.600 & 1.600 & 450 \\
Tepung Jagung & 450 & 450 & 385 \\
Bungkil Kedelai & 385 & 385 & 414 \\
Bungkil Kelapa & 414 & 414 & 100 \\
BIS & 100 & 100 & 360 \\
Mineral & 360 & 360 & $\mathbf{4 . 2 1 5}$ \\
Minyak Nabati & $\mathbf{4 . 2 7 9}$ & $\mathbf{4 . 2 4 7}$ & $\mathbf{4 . 6 7 8}$ \\
\hline Harga ransum (Rp/Kg) & $\mathbf{4 . 7 4 5}$ & $\mathbf{4 . 7 1 3}$ & \\
\hline Rataan Harga ransum $(\mathbf{R p} / \mathbf{K g})$ & & & \\
\hline Keterangan: & $\mathbf{T L}$ & & \\
\hline
\end{tabular}

Keterangan: TLIGP : Tepung Limbah Ikan Gabus Pasir

\section{Total Hasil Produksi}

Total hasil produksi atau total penerimaan yaitu seluruh produk yang dihasilkan dalam kegiatan ekonomi yang diperoleh dengan cara menghitung harga jual itik peking.

\section{Analisi Laba/Rugi}

Keuntungan (laba) suatu usaha diperoleh dengan cara:

$$
\pi=\mathrm{TR}-\mathrm{TC}
$$

Dimana:

$$
\begin{array}{ll}
\pi & =\text { keuntungan } \\
\mathrm{TR} & =\text { total penerimaan } \\
\mathrm{TC} & =\text { total pengeluaran }
\end{array}
$$

(Soekartawi, 1994). 


\section{Revenue Cost Ratio (R/C Ratio)}

$\mathrm{R} / \mathrm{C}$ nilai atau manfaat yang diperoleh dari setiap satuan biaya yang dikeluarkan R/C Ratio = Total Hasil Produksi

Total Biaya Produksi

R/C Ratio $>1=$ efesien

$\mathrm{R} / \mathrm{C}$ Ratio $=1=$ impas

$\mathrm{R} / \mathrm{C}$ Ratio $<1$ = tidak efesien

(Kadariah, 1987).

\section{Income Over feed Cost (IOFC)}

Income over feed cost (IOFC) diperoleh dengan cara menghitung selisih pendapatan usaha ternak dikurangi dengan biaya pakan. Pendapatan merupakan perkalian antara pertambahan bobot badan dengan harga jual. Sedangkan biaya pakan adalah biaya yang dikeluarkan untuk menghasilkan bobot badan ternak.

$\mathrm{IOFC}=($ bobot badan akhir itik $\mathrm{x}$ harga jual itik/kg) $-($ total konsumsi pakan $\mathrm{x}$ harga pakan perlakuan/kg) (Hermanto, 1996).

\section{HASIL DAN PEMBAHASAN}

\section{Total biaya produksi}

Tabel 2 di atas dapat dilihat bahwa biaya produksi selama pemeliharaan itik peking selama penelitian menunjukan perbedaan diantara berbagai perlakuan lainnya. yang mana rataan total biaya produksi tertinggi pada perlakuan P0 (Penggunaan ransum kontrol dengan tepung limbah ikan gabus pasir sebanyak 0\% dan tepung ikan komersil 10\%) dengan nilai rataan sebesar Rp. 229.527 /plot dan nilai rataan yang terendah pada perlakuan P2 (Penggunaan ransum dengan tepung limbah ikan gabus pasir sebanyak 10\% dan tepung ikan komersil 0\%) dengan rataan 224.289 /plot. Hal ini dikarenakan adanya perbedaan jumlah biaya ransum yang dikeluarkan pada pemeliharaan itik peking selama penelitian.

Tabel 1 di atas dapat dilihat bahwa rataan harga ransum tertinggi pada perlakuan P0 sebesar Rp. 4.745 dan rataan harga ransum terendah pada perlakuan P2 sebesar Rp. 4.678. Hal ini menyebabkan total biaya konsumsi pada P0 (10\% tepung ikan komersil) memberikan nilai yang lebih tinggi dibandingkan dengan P2 (10\% tepung limbah ikan gabus pasir) dengan nilai rataan sebesar Rp. 137.338,33,-,/plot sedangkan nilai pada P0 sebesar

Rp. 
142.576,07,-,/plot dan rataan total konsumsi pada P0 sebesar 32,7 kg/plot dan pada P2 sebesar $32,01 \mathrm{~kg} /$ plot.

Biaya produksi lebih banyak dihasilkan dari biaya pembelian ransum (sekitar 70\%). Hal inilah yang menyebabkan mengapa pada biaya produksi pada perlakuan P0 (10\% tepung ikan komersil) menjadi paling tinggi, karena total konsumsi ransum adalah sebesar 6,5 kg/ekor atau Rp 28.515/ekor, sedangkan itik yang mengkonsumsi ransum P2 (10\% tepung limbah ikan gabus pasir) menghasilkan biaya produksi terendah karena total konsumsi hanya sebesar 6,41 Kg/ekor atau Rp 27.468/ekor.

Biaya lainya seperti biaya bibit, biaya sewa kandang, biaya obat-obatan, biaya peralatan kandang dan biaya tenaga kerja dalam penelitian ini memberikan nilai yang sama. Hal ini sesuai dengan pernyataan Sugeng dan Sudarmono (2003), bahwa biaya produksi merupakan seluruh biaya yang dikeluarkan untuk menjalankan proses usaha. Jika seluruh biaya produksi usaha ternak dapat diketahui, maka keadaan harga persatuan produks akan mudah diperhitungkan

\section{Total Hasil Produksi}

Tabel 2 di atas dapat dilihat bahwa total hasil produksi pemeliharaan itik peking selama 8 minggu menunjukkan perbedaan pada setiap perlakuan. Pada total hasil produksi tertinggi terdapat pada perlakuan P2 (ransum dengan tepung limbah ikan gabus pasir sebesar 10\%) dengan nilai rataan sebesar Rp. 239.341,67,-,/plot dan total hasil produksi terendah pada perlakuan P0 (Penggunaan ransum kontrol dengan tepung limbah ikan gabus pasir sebanyak 0\% dan tepung ikan komersil 10\%) dengan rataan sebesar Rp. 230.941,67,-./plot.

Hal ini terjadi karena terdapat perbedaan bobot badan akhir itik peking, sehingga nilai pendapatan dari penjualan itik peking berbeda pada setiap perlakuan. Budiono (1990), menyatakan bahwa pendapatan adalah seluruh penerimaan uang yang diperoleh dari penjualan produk dari suatu kegiatan usaha seperti penjualan ternak hidup, kotoran, urun dan produk-produk lainnya yang dihasilkan merupakan komponen pendapatan.

Perlakuan P2 dengan penggunaan tepung limbah ikan gabus pasir sebesar $10 \%$ memberikan pertambahan bobot badan dengan rataan sebesar 1,36. $\mathrm{kg} / \mathrm{ekor}$ nilai tersebut lebih tinggi dibandingkan dengan perlakuan P0 tanpa mengunakan tepung limbah ikan gabus pasir dengan rataan sebesar 1,31. kg/ekor. Pertambahan bobot badan itik sangat mempengaruhi nilai total hasil produksi pemeliharaan itik peking. 
Tabel 2. Rekapitulasi hasil penelitian

\begin{tabular}{lccccc}
\hline \multirow{2}{*}{ Perlakuan } & $\begin{array}{c}\text { Parameter hasil penelitian } \\
\text { Total biaya }\end{array}$ & $\begin{array}{c}\text { Total hasil } \\
\text { produksi (Rp/plot) }\end{array}$ & $\begin{array}{c}\text { Laba rugi } \\
\text { (Rp/plot) }\end{array}$ & R/C & $\begin{array}{c}\text { IOFC } \\
\text { (Rp/plot) }\end{array}$ \\
\hline P0 & $229.527,64$ & $230.941,67$ & $1.414,03$ & 1,01 & $88.365,60$ \\
P1 & $225.461,67$ & $233.899,17$ & $8.437,50$ & 1,04 & $95.389,07$ \\
P2 & $224.289,94$ & $239.341,67$ & $15.051,73$ & 1,07 & $102.003,30$ \\
\hline Total & $679.426,24$ & $704.182,50$ & $24.903,26$ & 3,11 & $285.757,97$ \\
\hline
\end{tabular}

Tabel 3. Rekapitulasi hasil penelitian(Rp/ekor)

\begin{tabular}{lccccc}
\hline Perlakuan & \multicolumn{5}{c}{ Parameter hasil penelitian } \\
\cline { 2 - 6 } & $\begin{array}{c}\text { Total biaya } \\
\text { produksi(Rp/ekor) }\end{array}$ & $\begin{array}{c}\text { Total hasil } \\
\text { produksi(Rp/ekor) }\end{array}$ & $\begin{array}{c}\text { Laba rugi } \\
\text { (Rp/ekor) }\end{array}$ & R/C & $\begin{array}{c}\text { IOFC } \\
\text { (Rp/ekor) }\end{array}$ \\
\hline P0 & $45.905,52$ & $46.188,33$ & 282,80 & 1,01 & $17.673,12$ \\
P1 & $45.092,33$ & $46.779,83$ & $1.687,50$ & 1,04 & $19.077,81$ \\
P2 & $44.857,98$ & $47.868,33$ & $3.010,34$ & 1,07 & $20.400,88$ \\
\hline Total & $135.855,83$ & $140.836,49$ & $4.980,64$ & 3,12 & $57.151,81$ \\
\hline
\end{tabular}

Hal ini dikarenakan penjualan itik dihitung dengan harga perkilogram. Dengan demikian bahwa penggunaan tepung limbah ikan gabus pasir dengan level 10\% memberikan pengaruh yang baik terhadap pertambahan bobot badan itik peking.

Berdasarkan hasil penjualan itik peking diperoleh perlakuan P0 (10\% tepung ikan komersil) memiliki hasil yang terendah sebesar Rp. 230.941,67,-,/plot dan hasil penjualan itik peking tertinggi pada perlakuan P2 (10\% tepung limbah ikan gabus pasir) yaitu dengan nilai sebesar Rp. 239.341,67,-./plot. Penentuan pendapatan berdasarkan hasil penjualan itik peking sesuai dengan pernyataan Soekartawi (1995) yang menyatakan bahwa penerimaan merupakan perkalian antara produksi yang diperoleh dengan harga jual.

\section{Analisis Laba Rugi}

Tabel 2 dan 3 menunjukan nilai analisis laba/rugi pada penelitian itik peking selama 8 minggu dengan pemberian tepung limbah ikan gabus pasir subtitusi tepung ikan komersil. Pada perlakuan P0 (Ransum dengan tepung ikan komersil 10\%) memberikan keuntungan dengan rataan sebesar Rp. 4.734,19,-,/plot pada perlakuan P1 (tepung limbah ikan gabus pasir sebanyak 5\%) memberikan keuntungan dengan rataan sebesar Rp. 11.757,66,-,/plot dan perlakuan P2 (10\% tepung limbah ikan gabus pasir) memberikan keuntungan dengan rataan sebesar Rp. 18.372,-./plot.

Keuntungan tertinggi yaitu pada perlakuan P2 dengan hasil nilai rataan sebesar Rp. 18.372,-./plot atau Rp. 3.674 /ekor. Pendapatan tertinggi diperoleh pada penjualan itik peking yang diberikan ransum P2 karena pertambahan bobot badan itik peking lebih tinggi 
dibandingkan dengan perlakuan lainnya, sehingga total hasil produksi yaitu total penjualan itik peking memiliki nilai lebih tinggi dari pada total biaya produksi yaitu Biaya pakan, biaya bibit ternak itik peking, biaya peralatan, biaya obat-obatan, biaya sewa kandang dan biaya tenaga kerja. Hal ini sesuai dengan pernyataan dari Jumingan (2006) yang menyatakan bahwa laporan laba-rugi memperlihatkan hasil yang diperoleh dari penjualan jasa barang atau jasa dan ongkos-ongkos yang timbul dalam proses pencapaian hasil tersebut.

Analisis laba rugi ini juga memperlihatkan adanya pendapatan bersih atau kerugian bersih sebagai hasil dari operasi perusahaan selama periode tertentu. Laporan ini merupakan laporan aktivitas dan hasil dari aktivitas itu, atau merupakan ringkasan yang logis dari penghasilan dan biaya dari suatu perusahaan untuk periode tertentu. Besarnya laba ditentukan berdasarkan selisih antara nilai penjualan (total revenue) dengan total biaya (biaya tetap ditambah biaya variabel) pada tingakat volume produksi tertentu (Jumingan, 2006).

Keuntungan terendah terdapat pada perlakuan P0. Hal ini dikarenakan penerimaan dari penjualan itik pada pemberian ransum P0 terendah dibandingkan pemberian ransum perlakuan lainnya sehingga memberikan tingkat keuntungan yang rendah pula. Hansen dan Mowen (2001) menyatakan laba merupakan ukuran yang membedakan antara apa yang perusahaan masukan untuk membuat dan menjual produk dengan apa yang diterimannya. Perhitungan jelas untuk banyak untuk keputusan manajemen, jika laba konsisten positif perusahaan dapat tetap dalam bisnis tersebut tetapi jika mengalami kerugian perusahaan dapat mencari produk yang lain yang akan diolah dan dapat mendatangkan keuntungan bagi perusahaan.

\section{Analisis R/C Ratio}

Pada tabel 2 dapat dilihat bahwa nilai rataan $\mathrm{R} / \mathrm{C}$ ratio dalam penelitian ini adalah 1,01, 1,04 dan 1,07 yang menunjukan bahwa perlakuan P0, P1 dan P2 dianggap memiliki kelayakan usaha/efisien untuk dilanjutkan, karena nilai total hasil produksi dibagi dengan total biaya produksi memiliki nilai lebih besar dari $1(>1)$. Hal ini sesuai pernyataan dari Kadarsan (1995), yang menyatakan R/C rasio adalah rasio penerimaan atas biaya yang menunjukan besarnya penerimaan yang akan di peroleh dari setiap rupiah yang dikelurakan dalam produksi usaha ternak.

Usaha ternak dikatakan menguntungkan bila nilai R/C rasio lebih besar dari satu, yang artinya setiap satu rupiah biaya yang kita keluarkan untuk usaha ternak akan memberikan penerimaan lebih dari satu rupiah. Sebaliknya, usaha ternak dikatakan tidak menguntungkan bila $\mathrm{R} / \mathrm{C}$ ratio lebih kecil dari satu, hal ini berarti setiap satu rupiah yang kita keluarkan akan 
memberikan penerimaan kurang dari satu rupiah. Semakin besar nilai R/C maka semakin baik usaha ternak tersebut. Usaha ternak dikatakan impas apabila nilai $\mathrm{R} / \mathrm{C}$ ratio sama dengan satu.

\section{Income Over Feed Cost (IOFC)}

Tabel 2 dan 3 menunjukan nilai perbedaan dari setiap perlakuan yang mana pada perlakuan P0 dengan nilai rataan sebesar Rp. 17.673,12,-,/ekor yang merupakan rataan yang terendah, sedangkan rataan tertinggi yaitu pada perlakuan P2 sebesar Rp. 20.400,-,/ekor hal ini disebabkan karena bobot badan itik peking yang tinggi dikalikan dengan harga jual itik peking perkilogram, sehingga pendapatan dari hasil penjualan itik peking lebih tinggi dari pada total biaya yang dikeluarkan untuk konsumsi itik peking selama penelitian. Selain iti nilai IOFC dipengaruhi oleh tingkat konsumsi pakan yang tinggi diikuti dengan pertambahan bobot badan yang tinggi juga.

IOFC terendah pada perlakuan P0 dengan nilai rataan sebesar Rp. 17.673,12,-,/ekor. Hal ini dikarenakan bobot badan itik peking yang rendah dari perlakuan yang lainnya sehingga menyebabkan harga jual itik peking lebih rendah dibandingkan dengan perlakuan lainnya. Selain itu harga pakan pada setiap perlakuan juga dapat mempengaruhi rendahnya IOFC pada setiap perlakuan, hal ini yang menyebabkan IOFC pada perlakuan P0 lebih rendah dibandingkan dengan perlakuan lainnya.

Sesuai dari pernyataan Prawirokusumo (1990), yang menyatakan bahwa Income Over Feed Cost (IOFC) adalah selisih dari total pendapatan dengan total biaya pakan digunakan selama usaha penggemukan ternak. Income Over Feed Cost ini merupakan barometer untuk melihat seberapa besar biaya ransum yang merupakan biaya terbesar dalam usaha penggemukan ternak. IOFC diperoleh dengan menghitung selisih pendapatan usaha peternakan dikurangi biaya pakan. Pendapatan merupakan perkalian antara produksi peternakan atau pertambahan bobot badan akibat perlakuan dengan harga jual.

\section{KESIMPULAN}

Penggunaan tepung limbah ikan gabus pasir dengan level 10\% dapat meningkatkan total hasil produksi, R/C Ratio, analisis laba rugi dan IOFC (Income Over Feed Cost). Dan dapat menurunkan harga pakan, biaya konsumsi dan total biaya produksi pada pemeliharaan itik peking. Penggunaan tepung limbah ikan gabus pasir dengan level $10 \%$ dapat meningkatkan pendapatan dan menggantikan tepung ikan komersil dalam ransum ternak itik peking. 


\section{DAFTAR PUSTAKA}

Budiono, 1990. Ekonomi Mikro. Seri Sinopsis Pengantar Ilmu Ekonomi No. 1. Edisi kedua, Cetakan ke II. BPFE, Yogyakarta.

Cahyono, 2002. Wortel Teknik Budi daya Analis Usaha Tani. Kanisinus, Yogyakarta.

Hansen dan Mowen, 2001. Manajemen Biaya. Salemba Empat Patria, Jakarta.

Hermanto, F. 1996. Ilmu Usaha Tani. Penebar Swadaya, Jakarta.

Jumingan, 2006. Analisis Laporan Keuangan. PT Bumi Aksara, Jakarta.

Kadariah. 1987. Pengantar Evaluasi Proyek. Lembaga Penelitian Fakultas Ekonomi Universitas Indonesia, Jakarta.

Kadarsan, H. 1995. Keuangan Pertanian dan Pembiayaan perusaan agribisnis Cetakan Kedua. PT Gramedia Jakarta.

Murtidjo, 1987 Pedoman Meramu Pakan Unggas. Yayasan Kanisius, Yogyakarta.

Prawirokusumo, S. 1990. Ilmu Gizi Komparatif. BPFE, Yogyakarta.

Samosir, D, J., 1981. Ilmu ternak Itik. Gramedia Pustaka Utama, Jakarta.

Soekartawi, A. 1994 Analisis Cobb - Douglas. UI-Press, Jakarta. , 1995. Analisis usaha tani. UI-Press, Jakarta.

Sudarmono, A.S dan Y.B. Sugeng. 2003. Beternak Domba. Penebar Swadaya, Jakarta. 